\title{
TRANSMISSION OF Sclerotinia sclerotiorum FROM SOYBEAN SEED TO SEEDLINGS
}

\section{Cristiane de Carvalho ${ }^{1}$, Victor Augusto Forti ${ }^{2}$, Mauro Ferreira Bonfim Junior ${ }^{3}$, Maria Heloisa} Duarte Moraes ${ }^{3}$, José Otávio Machado Menten ${ }^{3}$

${ }^{1}$ Centro Paula Souza - ETEC “Martinho di Ciero”, E-mail: castelancarvalho@gmail.com

${ }^{2}$ Universidade Metodista de Piracicaba - UNIMEP, E-mail: viaugu@yahoo.com.br

${ }^{3}$ Escola Superior de Agricultura "Luiz de Queiroz" - ESALQ/USP, E-mail: mauroferreirajr@yahoo.com.br, mhdmorae@usp.br, jomenten@usp.br

\begin{abstract}
This paper evaluates the transmission of $S$. sclerotium from infected soybean seeds to seedlings. Results showed that a lower emergence percentage and speed was obtained after $24 \mathrm{~h}$ inoculation without asepsis; the transmission of S. sclerotiorum therefore occurred from soybean seeds to symptomatic seedlings. Asymptomatic seedlings do not present the fungus, indicating no transmission.
\end{abstract}

Keywords: Agar-bromophenol medium, Emergence percentage, Glycine max, Health test

\section{TRANSMISSÃO DE Sclerotinia sclerotiorum DE SEMENTES PARA PLÂNTULAS DE SOJA}

\section{RESUMO}

Essa pesquisa avaliou a transmissão de $S$. sclerotiroum de sementes de soja infectadas para plântulas. Os resultados mostraram baixa porcentagem de emergência para as sementes que foram inoculadas por $24 \mathrm{~h}$ sem assepsia; a transmissão de $S$. sclerotiorum ocorre de sementes de soja para plântulas com sintomas. Plântulas assintomáticas não apresentam fungo, indicando que não há transmissão.

Palavras-chave: Meio ágar-bromofenol, Porcentagem de emergência, Glycine max, Teste de sanidade

\section{INTRODUCTION}

Sclerotinia sclerotiorum (cottony

white rot) is a cosmopolitan fungus that infects more than 500 species of plants worldwide (SAHARAN \& MEHTA, 2008).
The control of this pathogen in several crops has been difficult due to its capacity to produce resistance structures (sclerotia), which could survive in the soil for several years, even in adverse conditions. Infected plants show the presence of fluffy white 
mycelium in lesions (BOLTON et al., 2006). In soybean (Glycine max (L.) Merrill), the symptoms appear mainly during the reproductive stage (KIMATI et al., 2005), generally in the third middle of the plants, reaching the main stem, petioles, leaves and pods (BOLTON et al., 2006).

The seed is the main dissemination vehicle, and the dissemination might be by the presence of sclerotia among seeds (HENNEBERG et al., 2012; KIMATI et al., 2005). Dormant mycelia have been shown to remain viable for more than three years, in infected seeds, without appreciable decrease in viability, when the air-dried seeds were stored at $4{ }^{\circ} \mathrm{C}$ (TU, 1988). The same author showed that when the seeds were sown, many of them did not germinate and were rotted by the fungus and there was the formation of many sclerotia. These sclerotia were then able to germinate both mycelially and carpogenically, depending on environmental conditions.

Rotation with susceptible crops, susceptible cultivars, infected soils and usage of infected seeds are factors which might be involved in the increase of the occurrence and the severity of $S$. sclerotiorum in the production fields. Therefore, one of the ways to preventing $S$. sclerotium from entering in free areas is the use of healthy or adequately treated seeds (KIMATI et al., 2005).

This pathogen has therefore been important in quality control programmes for seed companies, since they can be important dissemination vehicles of S. sclerotiorum, through sclerotia mixed in the seed mass or mycelia present in internal tissues (AGRIOS, 2005). However, the transmission to the seedlings is not completely understood. Experiments performed with common beans (KOCH, 2001) naturally infected by $S$. sclerotiorum did not produce seedlings with white mould symptoms.

This paper aimed to investigate the transmission of S. sclerotium from infected soybean seeds to seedlings.

\section{MATERIAL AND METHODS}

Two experiments were performed, in two consecutive years, using soybean seeds from the cultivar TMG123-RR, produced in Alto Garças area (16 56'38', $S$ and 5331'41',W), Mato Grosso State, Brazil in 2009/2010 season, which were, initially characterized in terms of their health and germination.

For the experiments the seeds were inoculated with $S$. sclerotiorum to a level of incidence that could be studied. Generally, 
the percentage of naturally infected seeds is, too low, varying from $0.25 \%$ to $1 \%$.

All the seeds were initially submitted to superficial asepsis with sodium hypochlorite $1 \%$ for three minutes, and kept in the laboratory at room temperature for 24 hours. Subsequently, the seeds were placed in Petri dishes containing pure pathogen colonies, (characterized by white and fluffy mycelia), and were kept in an incubator at $20 \pm 2{ }^{\circ} \mathrm{C}$ for $18 \mathrm{~h}$ and $24 \mathrm{~h}$ The same $S$. sclerotiorum isolate was used in the two consecutive years experiments. Simultaneously some non-inoculated seeds were put in direct contact with the PDA medium (potato-dextrose-agar) without the fungus, for the same $18 \mathrm{~h}$ or $24 \mathrm{~h}$ for later evaluation of the possible effects of this procedure on the seedlings emergence. After this inoculation phase, the seeds were taken out of the Petri dishes and kept in the laboratory at room temperature for $24 \mathrm{~h}$ again, so that the seed moisture content achieved hygroscopic equilibrium with the relative humidity of the air.

The incidence of S. sclerotium was evaluated using agar-bromophenol medium (PDA+105 mg.L ${ }^{-1}$ of bromophenol blue, 150 mg. $\mathrm{L}^{-1}$ of streptomycin sulphate and 140 mg. $\mathrm{L}^{-1}$ of penicillin) (STEADMAN et al., 1994) and it was assessed for four treatments: seed inoculation for $18 \mathrm{~h}$ or $24 \mathrm{~h}$ with asepsis in 1\% sodium hypochlorite for three minutes, and inoculation for $18 \mathrm{~h}$ or $24 \mathrm{~h}$ without asepsis. For each treatment, four replicates of 50 seeds were incubated at $20 \pm 2{ }^{\circ} \mathrm{C}$ with alternation (12h) of light near ultraviolet (NUV). They were observed daily to check the yellowish halos around the seeds. The presence of yellowish halo is an indication of the presence of the $S$. sclerotiorum, because the oxalic acid produced by the fungus changes the colour of the medium from blue to yellow. In order to confirm the presence of $S$. sclerotium, the dishes were observed under white light, which made it possible to visualize any mycelium coming from the seeds on the culture medium in the area of the yellowish halo. The result of incidence of infection was expressed as percentage of seeds with the presence of $S$. sclerotiorum. The test used to evaluate the transmission of $S$. sclerotiorum from the seeds to the seedlings was the emergence test in greenhouse. The physiological potential of the seeds was also evaluated through speed and percentage of the seedling emergence. For this, three more treatments were added to the four already described: control seeds (not submitted to inoculation processes) and seeds which were 
in contact with the PDA medium without the fungus for $18 \mathrm{~h}$ and $24 \mathrm{~h}$

Four replicates of 50 seeds of each treatment were sown in trays containing vermiculite and kept in a greenhouse until seedlings developed, for at least 20 days. The variations in greenhouse temperature were registered (Figure 1). During development, the speed of emergence index (MAGUIRE, 1962) and the emergence percentage were evaluated. Emerged seedlings were considered as those in which the cotyledons were completely grown out of the substrate, angled in parallel to its surface.

At the final emergence stage, seedlings and seeds were assessed for the presence of mycelium and seedlings which had died after emergence due to the presence of S. sclerotiorum. Some seeds with mycelium could be seen on the surface of the substrate. In addition, the transmission rate of $S$. sclerotiorum to soybean seedlings was determined based on the division of the percentage of seedlings with mycelium by the percentage of pathogen incidence in the health test.

Twenty days after the sowing, 20 emerged seedlings were randomly chosen with or without symptoms of white mould. These seedlings were cut into two segments of $1 \mathrm{~cm}$; one segment was taken from the epicotyl and the other from the hypocotyl. This tissue was submitted to asepsis with $1 \%$ sodium hypochlorite for $1 \mathrm{~min}$ and subsequently alcohol $70 \%$ for 2 s, placed in agar-bromophenol medium and incubated in an incubation room at $20 \pm 2{ }^{\circ} \mathrm{C}$ with NUV alternation $(12 \mathrm{~h})$ in order to confirm the transmission. 


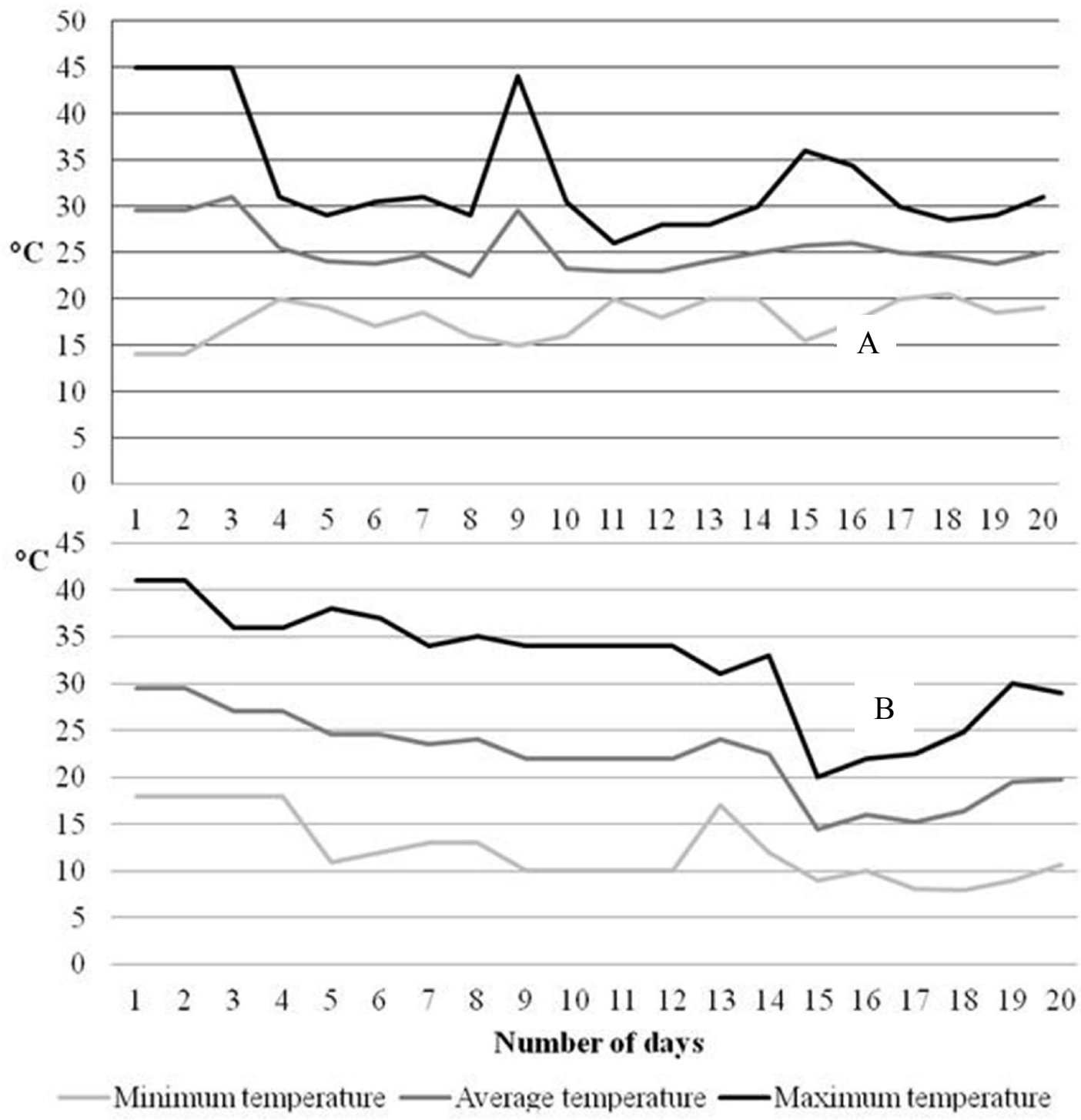

Figure 1. Greenhouse maximum, average and minimum temperature, in ${ }^{\circ} \mathrm{C}$, during the period of the seedling emegence test of soybean seeds in the first (A) and second (B) experiment (Piracicaba, $A$ Oct 2010/ B May 2011)

Along with that analysis, parts of the tissue of the seedlings, such as cotyledons and hypocotyls, in which the symptoms of $S$. sclerotiorum were unclear, were put in contact with the agar-bromophenol medium in order to confirm the presence of the pathogen. Not only the segments of hypocotyls, but also other tissues of seedlings were individually identified on the Petri dishes to facilitate assessments.

The experimental design was completely randomized with four treatments and four replications (for the experiment of S. sclerotium detection in the seeds) and seven treatments and four replications (for the experiment of transmission). The average 
of each treatment was compared by the Tukey test at $5 \%$ of probability.

\section{RESULTS AND DISCUSSION}

The initial germination of the control seeds used for this research was $92 \%$ and the incidence of S. sclerotiorum was $0 \%$, which demonstrates the importance of the inoculation procedure. The early determination of the seed health was important for the decision made regarding the inoculation later carried out, because there was not natural incidence of the pathogen.

In the seed health test through agarbromophenol medium, a higher incidence of the pathogen was observed in the seeds inoculated for $24 \mathrm{~h}$ compared to those inoculated for $18 \mathrm{~h}$ in the treatments with and without asepsis (Table 1 and Figure 2). The incidence of the fungus was higher in the treatments without asepsis. However, the asepsis with sodium hypochlorite allowed estimating the level of infection of $S$. sclerotiorum in the seeds. The contact of those with sodium hypochlorite at $1 \%$ for three minutes caused the death of the fungi that were on the surface of the seeds, which left, at the end of the health test, only the mycelium which was present inside the seeds. The inoculum that remained after asepsis may have lower capacity of survival for longer time and have a lower probability of causing disease in the plant (BOTELHO et al., 2008).

Besides having shown good results for the incidence evaluation, the agarbromophenol medium, used for the health test, needs to be kept and evaluated until the moment of mycelium and/or sclerotia formation for the confirmation of the fungus. In many cases, it was observed the presence of yellowish halo around the seeds; however, the occurrence of other contaminating fungi, also acidify the agar-bromophenol medium and make it yellow, like fungi of the genera Aspergillus and Rhizopus, among others (HENNEBERG et al., 2012).

The percentage of emerged seedlings was lower for all the inoculation treatment with S. sclerotiorum on the first experiment, while in the second, reduction occurred only on the seeds which were in contact with the fungus for $24 \mathrm{~h}$ and was not submitted to asepsis (Table 1), demonstrating a better efficiency of the first inoculation. 
Table 1. Sclerotinia sclerotiorum incidence (\%) evaluated by health test in agar-bromophenol medium $(\mathrm{H})$, emerged plants (EP) and speed emergence index (SEI) for inoculation treatments in soybean seeds, in both experimental periods (Piracicaba, First Oct 2010/ Second May 2011).

\begin{tabular}{|c|c|c|c|}
\hline \multicolumn{4}{|c|}{ FIRST EXPERIMENT } \\
\hline \multirow{2}{*}{ Treatment } & $\mathrm{H}$ & EP & \multirow{2}{*}{ SEI } \\
\hline & \multicolumn{2}{|c|}{$\%$} & \\
\hline Control & - & $93 \mathrm{a}$ & $8.5 \mathrm{a}$ \\
\hline $18 \mathrm{~h} \mathrm{PDA}^{1}$ & - & 89 a & $7.3 \mathrm{a}$ \\
\hline $24 \mathrm{~h} \mathrm{PDA}^{2}$ & - & $73 \mathrm{~b}$ & $5.3 \mathrm{~b}$ \\
\hline $18 \mathrm{~h} \mathrm{a}^{3}$ & $16 \mathrm{a}$ & $76 \mathrm{~b}$ & $5.9 \mathrm{~b}$ \\
\hline $24 \mathrm{~h} \mathrm{a}^{4}$ & $36 \mathrm{~b}$ & $72 \mathrm{~b}$ & $5.8 \mathrm{~b}$ \\
\hline $18 \mathrm{~h} \mathrm{n.a.}{ }^{5}$ & $52 \mathrm{c}$ & $64 \mathrm{~b}$ & $5.2 \mathrm{~b}$ \\
\hline 24 h n.a. ${ }^{6}$ & $62 \mathrm{c}$ & $42 \mathrm{c}$ & $3.6 \mathrm{c}$ \\
\hline \multirow[t]{2}{*}{$\mathrm{CV}(\%)$} & 3.9 & 7.4 & 8.5 \\
\hline & \multicolumn{2}{|c|}{ SECOND EXPERIMENT } & \\
\hline \multirow{2}{*}{ Treatment } & $\mathrm{H}$ & EP & \multirow{2}{*}{ SEI } \\
\hline & \multicolumn{2}{|c|}{$\%$} & \\
\hline Control & - & $97 \mathrm{a}$ & $8.4 \mathrm{a}$ \\
\hline $18 \mathrm{~h}$ PDA & - & $95 \mathrm{a}$ & $7.7 \mathrm{ab}$ \\
\hline $24 \mathrm{~h}$ PDA & - & $95 \mathrm{a}$ & $8.6 \mathrm{a}$ \\
\hline $18 \mathrm{~h} \mathrm{a}$. & $4 \mathrm{a}$ & $90 \mathrm{a}$ & $7.8 \mathrm{ab}$ \\
\hline $24 \mathrm{~h} \mathrm{a}$. & $9 \mathrm{~b}$ & $87 \mathrm{a}$ & $7.4 \mathrm{ab}$ \\
\hline $18 \mathrm{~h} \mathrm{n.a.}$ & $32 \mathrm{c}$ & $88 \mathrm{a}$ & $7.9 \mathrm{ab}$ \\
\hline 24 h n.a. & $49 \mathrm{c}$ & $70 \mathrm{~b}$ & $6.1 \mathrm{~b}$ \\
\hline CV $(\%)$ & 12.3 & 1.2 & 5.8 \\
\hline \multicolumn{4}{|c|}{$\begin{array}{l}18 \text { hours in contact with PDA } \\
224 \text { hours in contact with PDA } \\
3 \text { 18 hours of inoculation with } S . \text { sclerotiorum with asepsis } \\
{ }^{4} 24 \text { hours of inoculation with } S . \text { sclerotiorum with asepsis } \\
518 \text { hours of inoculation with } S \text {. sclerotiorum without asepsis } \\
{ }^{6} 24 \text { hours of inoculation with } S \text {. sclerotiorum without asepsis }\end{array}$} \\
\hline
\end{tabular}




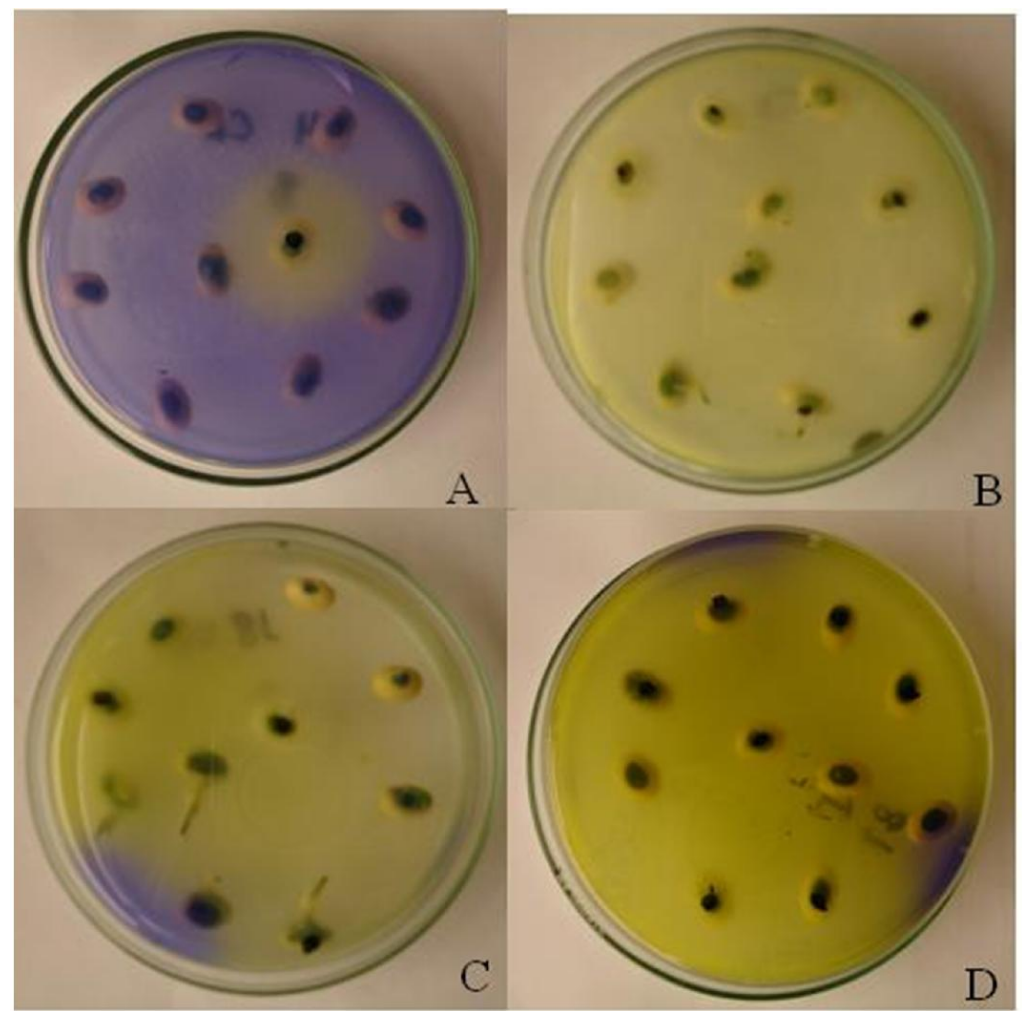

Figure 2. Evaluation of Sclerotinia sclerotiorum incidence on agar-bromophenol medium of inoculated soybean seeds. A - inoculation for 18 hours with asepsis; B - inoculation for 18 hours without asepsis; C - inoculation for 24 hours with asepsis; D inoculation for 24 hours without asepsis (Piracicaba, Oct 2010/May2011).

The average greenhouse temperature for both experiments was similar during the whole period (Figure 1), which shows that the differences in percentage of emerged seedlings were probably due to the inoculation process and pathogen efficiency and not to the temperature in the greenhouse. In the second experiment, the effect of the inoculation was less efficient than in the first, probably because of successive pricking-outs for the maintenance of the isolate. The incidence of the pathogen was lower, but it also decreased the seedlings emergence and the emergence speed. The asepsis reduced the incidence of the pathogen and, as a consequence, reduced its effect on the seedlings emergence.

The inoculation for $18 \mathrm{~h}$ did not interfere in the physiological potential of the seeds; therefore, the reduction of the emergence of this treatment, for the first experiment, might be exclusively due to the effect of the pathogen. Hoffman et al. (1998) reported that, for the soybean cultivars P9381, Yale, P9342 and A3304, the seed germination was reduced with the increase of incidence of S. sclerotiorum. The same author observed transmission of the fungus 
in the maximum $0.7 \%$ for seedlings in germination roll.

Based on the seedlings emergence data in greenhouse, it was observed that the contact of $24 \mathrm{~h}$ in the medium culture without the fungus affected the physiological potential of the seeds for the first experiment (Table 1), which caused reduction of 20 percentage points in the seedling emergence. The contact of the seeds with the medium culture decreased the physiological potential of the seeds for the first experiment. In this case, the PDA medium could be less consistent or could have condensed water over the medium. Both conditions would allow a higher absorption of water by the seeds and, as a consequence, cause a reduction of the physiological potential. Moreover, the contact with the medium might have decreased the seeds vigor; in addition, the temperature conditions and relative humidity of the air and of the substrate in the greenhouse could have contributed for the lowering of the percentage and speed of seedlings emergence in the first experiment.

The presence of S. sclerotiorum in the seeds also interfered in the speed of the seedlings emergence similarly to the percentage of emergence for both experiments. In the treatment with seeds inoculated for $24 \mathrm{~h}$ without asepsis, the speed emergence index (SEI) was lower as compared to the other treatments in the first experiment (Table 1).

The percentage of dead seedlings (DSe) and seed (DS), seedlings (SeM) and seeds with mycelium (SM) and the transmission rate (TR), for both experiments, are in Table 2. Dead seedlings were observed only on treatments inoculated with the fungus for the first experiment and all of them there were $S$. sclerotiorum mycelial growth.

For the seeds submitted to contact with the fungus for $18 \mathrm{~h}$ at the first experiment, there was a difference in the number of dead seeds between the ones of direct contact with PDA only and the inoculated, submitted or not to asepsis. These results showed that after inoculation with the fungus, it set itself in the seeds, which caused their deaths. Among the seeds submitted only to PDA and those inoculated for $24 \mathrm{~h}$ with asepsis, there was not a difference in the percentage of dead seeds, despite the presence of $5 \%$ of seeds with mycelium of S. sclerotiorum. For the other analysis, the highest and the lowest transmission rate was of $6.3 \%$ and $3.2 \%$, respectively, for the treatments of seeds 
inoculated for $18 \mathrm{~h}$ with asepsis and seeds inoculated for $24 \mathrm{~h}$ without asepsis (Table 2).

In the second experiment, mycelium was observed in all cases of dead seed, which shows that these deaths were caused by the presence of the pathogen and not by the inoculation procedure, because when the seeds stayed only in the PDA medium for $18 \mathrm{~h}$ and $24 \mathrm{~h}$, there was no occurrence of dead seeds (Table 2). Only for the inoculation treatment for $24 \mathrm{~h}$ without asepsis the presence of seedling with mycelium was observed, that resulted in a transmission rate of $4.1 \%$.

Similarly to the seedlings development evaluations, when the occurrence of dead seeds or seedlings with mycelium was evaluated, the highest incidences occurred in the first experiment. Therefore, a transmission rate of $S$. sclerotiorum was observed in soybean seedlings, being $5.5 \%$ and $3.2 \%$ for the seedlings from seeds submitted to $24 \mathrm{~h}$ of inoculation with and without asepsis, respectively, and $6.3 \%$ and $5.8 \%$ for the ones inoculated for $18 \mathrm{~h}$ with and without asepsis, respectively, for the first experiment (Table $2)$. For the second experiment a transmission rate of $4.1 \%$ was observed for the seedlings from seed submitted to inoculation of $24 \mathrm{~h}$ without asepsis. These high transmission rates showed that, when associated to the seed, the transmission of $S$. sclerotiorum to seedlings is very important and may be a determining factor in the health quality of a soybean field.

Thereby, besides the low transmission rate in symptomatic seedlings, if we consider a population of 240 thousand plants per hectare and considering the percentage of seedlings with a $2 \%$ mycelium, it would be possible to obtain 4,800 seedlings with incidence of the pathogen which may or not result in infected plants with the formation of sclerotia. If it is considered that up to $5 \%$ of the seed died due to the presence of the pathogen, in the same population of 240 thousand plants per hectare there would be more 12,000 source of inoculum in the field.

In many dead seedlings, it was observed symptoms of the disease and mycelium of the fungus in the strap of the hypocotyls (Figure 3C), in the cotyledons (Figure 3A, 3B, 3C, 3E, 3F) and in the seedcoat (Figure 3D), confirmed by the incubation of these tissues in agarbromophenol medium. These symptoms were characterized, at first, as "soaked" brown colored tissues with later growth of mycelium in the surface. 
Table 2. Percentage of dead seedlings (DSe), dead seeds (DS), seedlings with mycelium (SeM), seeds with mycelium (SM) and transmission rate (TR) of soybean seeds inoculated with S. sclerotiorum in both experimental periods. (Piracicaba, First Oct 2010/Second May2011)

FIRST EXPERIMENT

\begin{tabular}{cccccc}
\hline \multirow{2}{*}{ Treatment } & DSe & DS & SeM & SM & TR \\
\cline { 2 - 6 } & & & $\%$ & & \\
\hline Control & $0 \mathrm{a}$ & $8 \mathrm{a}$ & $0 \mathrm{a}$ & $0 \mathrm{a}$ & - \\
18 h PDA $^{1}$ & $0 \mathrm{a}$ & $11 \mathrm{a}$ & $0 \mathrm{a}$ & $0 \mathrm{a}$ & - \\
24 h PDA $^{2}$ & $0 \mathrm{a}$ & $27 \mathrm{~b}$ & $0 \mathrm{a}$ & $0 \mathrm{a}$ & - \\
18 h a. $^{3}$ & $1 \mathrm{a}$ & $25 \mathrm{~b}$ & $1 \mathrm{a}$ & $1 \mathrm{a}$ & 6.3 \\
24 h a. $^{4}$ & $2 \mathrm{a}$ & $28 \mathrm{~b}$ & $2 \mathrm{a}$ & $5 \mathrm{~b}$ & 5.5 \\
18 h n.a. $^{5}$ & $3 \mathrm{a}$ & $36 \mathrm{~b}$ & $3 \mathrm{a}$ & $4 \mathrm{~b}$ & 5.8 \\
24 h n.a. & $2 \mathrm{a}$ & $58 \mathrm{c}$ & $2 \mathrm{a}$ & $5 \mathrm{~b}$ & 3.2 \\
\hline CV (\%) $^{6}$ & 98.0 & 15.3 & 98.0 & 73.5 & \\
\hline Treatment & DSe & DS & SeM & SM & TR \\
\hline Control & 0 & $0 \mathrm{a}$ & $0 \mathrm{a}$ & $0 \mathrm{a}$ & - \\
18 h PDA & 0 & $0 \mathrm{a}$ & $0 \mathrm{a}$ & $0 \mathrm{a}$ & - \\
24 h PDA & 0 & $0 \mathrm{a}$ & $0 \mathrm{a}$ & $0 \mathrm{a}$ & - \\
18 h a. & 0 & $1 \mathrm{a}$ & $0 \mathrm{a}$ & $0 \mathrm{a}$ & 0.0 \\
24 h a. & 0 & $2 \mathrm{a}$ & $0 \mathrm{a}$ & $2 \mathrm{ab}$ & 0.0 \\
18 h n.a. & 0 & $3 \mathrm{ab}$ & $0 \mathrm{a}$ & $3 \mathrm{~b}$ & 0.0 \\
24 h n.a. & 0 & $5 \mathrm{~b}$ & $2 \mathrm{a}$ & $5 \mathrm{~b}$ & 4.1 \\
\hline CV (\%) & & 49.3 & 96.3 & 18.6 & \\
\hline 18 ho EXPRIMENT & & & \\
\hline
\end{tabular}

18 hours in contact with PDA

224 hours in contact with PDA

${ }^{3} 18$ hours of inoculation with $S$. sclerotiorum with asepsis

${ }^{4} 24$ hours of inoculation with $S$. sclerotiorum with asepsis

${ }^{5} 18$ hours of inoculation with $S$. sclerotiorum without asepsis

${ }^{6} 24$ hours of inoculation with $S$. sclerotiorum without asepsis 


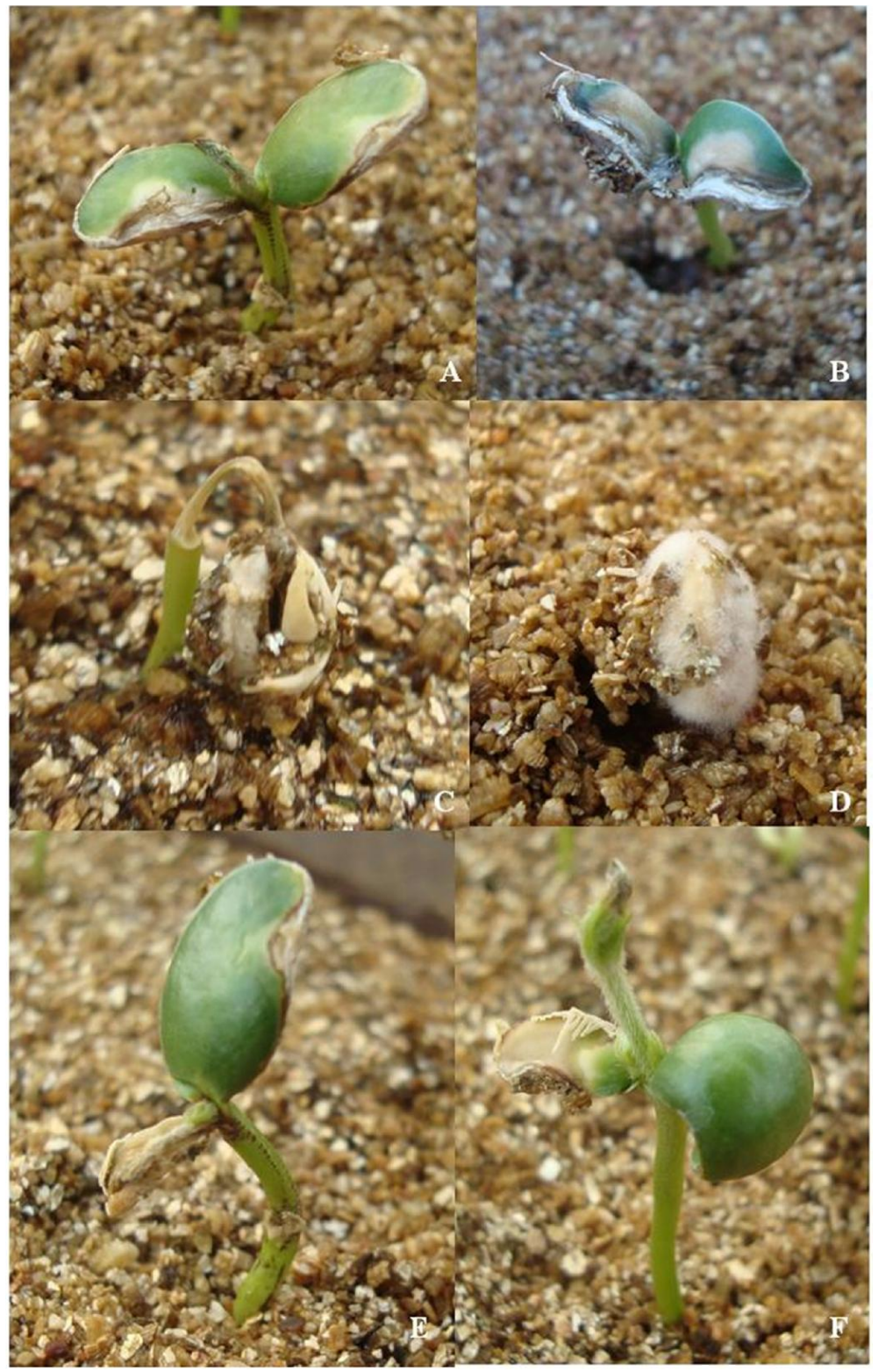

Figure 3. Soybean seedlings with Sclerotinia sclerotiorum symptoms. A, B, E and F: symptoms in cotyledons, C: symptom in strap hypocotyl, D: mycelium on the surface of cotyledons (Piracicaba, Oct 2010/May2011).

Bolton et al (2006), in his research about Sclerotinia sclerotiorum biology, affirmed that this is a necrotrophic homothallic pathogen. As S. sclerotiorum has a large host range, there are no unique symptoms that belong to all plants infected by this fungus. However, lesions usually develop into necrotic tissues that subsequently develop patches of fluffy white mycelium, which are the most obvious sign of plants infected with $S$. sclerotiorum (BOLTON et al., 2006). 
The symptoms in seedlings and seeds incidences were due to the production of oxalic acid by S. sclerotiorum (KIM et al., 2008), the same acid which alters the color of the agar-bromophenol medium. Livingstone et al. (2005) applied varying concentrations of oxalic acid to the surface of detached peanut leaflets that showed that the higher oxalic acid concentration, the greater the lesions on leaflets. Oxalic acid may aid in infection through a number of proposed routes, including acidification to facilitate cell wall-degrading enzyme activity, through $\mathrm{pH}$-mediated tissue damage, or via sequestration of $\mathrm{Ca}^{2+}$ ions (LIVINGSTONE et al. 2005). The oxalate secreted by the fungus induces the production of reactive oxygen species in the plant host that appears to trigger a programmed cell death pathway, which results in plant cell death and the generation of a suitable environmental niche for fungal pathogenic development, nutrients acquisition and the establishment of a necrotrophic relationship (KIM et al., 2008).

In some seedlings there was mycelial growth in the cotyledons and in the seedcoat (Figure 3D), which prevented their opening and the exposition of the primary leaves. After the mycelium growth, the tissues underwent dehydration, which caused death of the seedling. However, in some cases, the presence of symptoms was observed in the cotyledons without the occurrence of abnormality or seedlings death, once the damage was lower than $50 \%$ of the area of the cotyledons and it was limited to the boundaries of this tissue.

On the test performed with asymptomatic seedlings, 20 days after sowing, the presence of S. sclerotiorum was not observed either in the epicotyls or in the hypocotyls. The transmission was verified only through the observation of symptomatic seedlings and the confirmation from the incubation in agar-bromophenol medium. When the symptoms occurred in the cotyledons, the presence of the fungus was not observed in the hypocotyls and epicotyls, as it could be seen in beans (KOCH, 2001).

\section{CONCLUSION}

As a conclusion, the transmission of S. sclerotiorum occurs from soybean seeds to symptomatic seedlings. Asymptomatic seedlings do not present the fungus, which indicates no transmission.

\section{REFERENCES}

AGRIOS, G.N. 2005. Plant Pathology. San Diego: Elsevier Academic Press, $5^{\text {th }}$ ed. $635 \mathrm{p}$. 
BOLTON, M.D., THOMMA, B.P.H.J.; NELSON, B.D. 2006. Sclerotinia sclerotiorum (Lib.) de Bary: biology and molecular traits of a cosmopolitan pathogen. Molecular Plant Pathology, v.7, n.1, London, p.1-16.

BOTELHO, L.S., MORAES, M.H.D.; MENTEN, J.O.M. 2008. Fungi associated to the seeds of ipê-amarelo (Tabebuia serratifolia) and ipê-roxo (Tabebuia impetiginosa): incidence, germination effect and seedlings transmission. Summa Phytopathologica, Jaguariuna, v. 34, n.4, p. 343-348.

HENNEBERG, L.; JACCOUD FILHO, D. S.; RUARO, L.; PANOBIANCO, M. 2012. Efficiency of methods to detect Sclerotinia sclerotiorum in commercial soybean seed lots. Revista Brasileira de Sementes,Londrina, v.34, n.1, p.61-69.

HOFFMAN, D.D., HARTMAN, G.L., MUELLER, D.S., LEITZ, C.V., NICKELL, C.D.; PEDERSEN, W.L. 1998. Yield and seed quality of soybean cultivars infected with Sclerotinia sclerotiorum. Plant Disease, Saint Paul, v.82, n.7, p.826-828.

KIM, K.S., MIN, J.Y.; DICKMAN, M.B. 2008. Oxalic acid is an elicitor of plant programmed cell death during Sclerotinia sclerotiorum disease development. Molecular Plant-Microbe Interactions, Saint Paul, v.21, n.5, p.605-612.

KIMATI, H.; AMORIM, L.; REZENDE, J.A.M.; BERGAMIM FILHO, A.; CAMARGO, L.E.A. 2005. Manual de fitopatologia: doenças de plantas cultivadas. São Paulo: Agronômica Ceres, 4ª ed. 663p.

KOCH, E.F.A. 2001. Effect of Sclerotinia sclerotiorum on the initial growth of common bean seedlings. Summa Phytopathologica, Jaguariuna, v. 27, p. 6873.

LIVINGSTONE, D.M.; HAMPTON, J.L.; PHIPPS, P.M.; GRABAU, E.A. 2005.
Enhancing resistance to Sclerotinia minor in peanut by expressing a barley oxalate oxidase gene. Plant Physiology, Washington, v.137, n.4, p.1354-1362.

MAGUIRE, J.D. 1962. Speed of germination-aid in selection and evaluation for seedling emergence and vigor. Crop Science, Madison, v.2, n.2, p.176-177.

SAHARAN, G.S.; MEHTA, N. 2008. Sclerotinia diseases of crop plants: biology, ecology and disease management. London: Springer, 486p.

STEADMAN, J.R., MARCINKOWSKA, J.; RUTLEDGE, S. 1994. A semi-selective medium for isolation of Sclerotinia sclerotiorum. Canadian Journal of Plant Pathology, Ontario, v.16, n.1, p.68-70.

TU, J.C. 1988. The role of white moldinfected white bean (Phaseolus vulgaris L.) seeds in the dissemination of Sclerotinia sclerotiorum (Lib.) de Bary. Journal of Phytopathology, Berlin, v.121, n.1, p.40-50.

Recebido em: 25/6/2015 Aceito para publicação em: 24/3/2016 